\author{
Kerimova Zh.K. ${ }^{l}$, Akhapov E.A. ${ }^{1}$, Shimizu $K^{2}$ \\ ${ }^{1}$ Al-Farabi Kazakh national university \\ Tottori University
}

\title{
YOKOHAMA ECO-MODEL CITY'S POLICY ON WASTE MANAGEMENT
}

\section{Abstract}

Projects transforming the concept of eco-city into practices became a challenge to the Eastern countries to countermeasure with the global warming and climate change. We can be witnesses of rising number of significant eco-city models than might be a real fine model to other countries and cities that would like to change their current environmental situation. In particular Japan Government launched "Eco-model cities" program in 2008, to create model cities replicable elsewhere both in Japan and in the world.

This paper provides research results about the environmental policy on municipal solid waste (MSW) management of Japan's eco-model city of Yokohama, which led the city to show one of the best performances on waste reduction. Yokohama city was designated as one of the eco-model city in 2008, although its well-known waste reduction plan was established in 2003. From that period local government, residents and companies work together to achieve common goal.

Keywords: eco-model city, Yokohama, municipal solid waste management

$$
\begin{gathered}
\text { Ж.Қ.Керімова }{ }^{l}, \text { Е.А.Ахапов }{ }^{1}, \text { К.Шимидзу }{ }^{2} \\
{ }^{l} \text { Әл-Фараби атындавы Казақ ұлттық университеті } \\
{ }_{2}^{2} \text { Тоттори Университеті }
\end{gathered}
$$

\section{ЙОКОХАМА ЭКО-МОДЕЛЬ КАЛАСЫНЫН ҚАЛДЫҚТАРДЫ БАСКАРУ СЕКТОРЫНДАҒЫ САЯСАТЫ}

\author{
Анцатпа
}

Эко-қала тұжырымдамасын тәжірибеге айналдыратын жобалар Шығыс елдерінің ғаламдық жылыну мен климаттың өзгеруіне қарсы тұру үшін сын-тегеурінге айналды. Біз қазіргі экологиялық жағдайын өзгерткісі келетін елдер мен қалалар үшін нақты үлгі бола алатын, көрнекті эко-қала модельдері санының өсуіне куә болып келеміз. Атап айтқанда, Жапония Үкіметі 2008 жылы өз елінде де, әлемде де үлгі бола алатын қалаларды құру үшін «Эко-модель қалалар» бағдарламасын іске қосты.

Бұл жұмыста қоқысты азайту бойынша ең жақсы жетістікке қол жеткізген қалалардың біріне айналған Жапонияның Йокохама эко-модель қаласының қатты тұрмыстық қалдықтарды (MSW) басқару жөніндегі экологиялық саясаты туралы зерттеудің нәтижесі берілген. Йокохама қаласы 2008 жылы эко-модель қалалардың бірі ретінде белгіленді. Дегенмен оның қалдықтарды азайту жөніндегі әйгілі жоспары 2003 жылы құрылды. Сол кезеңнен бері жергілікті үкімет, қала тұрғындары мен компаниялар ортақ мақсатқа жету үшін бірлесіп жұмыс істеп келеді.

Түйінді сөздер: эко-модель қала, Йокохама, тұрмыстық қатты қалдықтарды басқару

$$
\begin{aligned}
& \text { Керимова Ж.К. }{ }^{l}, \text { Ахапов Е.А. }{ }^{l}, \text { Шимидзу } K .^{2} \\
& { }^{1} \text { Казахский национальньй университет имени аль-Фараби } \\
& { }^{2} \text { Университет Тоттори }
\end{aligned}
$$




\section{ПОЛИТИКА УПРАВЛЕНИЯ ОТХОДАМИ ЭКО-МОДЕЛИ ГОРОДА ЙОКОГАМА}

\section{Аннотащия}

Проекты превращающие концепцию эко-города в практическую деятельность стали для стран Востока задачей противодействия глобальному потеплению и изменению климата. Мы можем быть свидетелями растущего числа значимых моделей эко-городов, которые могут стать отличной моделью для других стран и городов, которые хотели бы изменить свою текущую экологическую ситуацию. В частности, Япония запустила программу «Эко-модель города» в 2008 году, чтобы создать модели городов, которые можно будет воспроизводить в других местах как в Японии, так и в мире.

В настоящей работе представлены результаты исследования об экологической политике управления твердыми бытовыми отходами (ТБО) в японском эко-модель городе Йокогама, благодаря которой город продемонстрировал одно из лучших достижений в области сокращения отходов. Город Йокогама был определен как один из эко-модель городов в 2008 году, однако его широко известный план сокращения отходов был создан в 2003 году. С того времени местная власть, жители и компании работают вместе для достижения общей цели.

Ключевые слова: эко-модель города, Йокогама, управление твердыми бытовыми отходами

\section{Introduction}

The last century has seen notable changes in how mankind consumes and uses goods and services. As the result garbage, waste, rubbish and litter are now generated at almost all stages of mankind activity. About 13 billion tons of new municipal solid waste was created in 2000, and the quantity of waste generated in OECD countries almost doubled from 1980 to 2005 [1, p.35]. The amount of municipal solid waste in developing countries has been consistently growing too. But municipal solid waste disposal in most developing countries creates serious environmental problems. For instance, in Kazakhstan, outside of the metropolitan cities, about 3 quarters of the population don't have an access to MSW collection services. The reason of that is technology and infrastructure do not meet current standards and requirements due to a lack of economic incentives, even if they are in place, enforcement is very weak [2, p.565]. In addition, MSW management is costly for local governments in developing Asian countries. According to the World Bank, those costs account for more than half of local governments' budgets. The list of developing and developed countries of Asian continent, made by World Bank is shown in Table 1 [3, p.592-593].

Table 1. Developing and developed countries of Asia, based on levels of economic development as defined by the World Bank (2016)

\begin{tabular}{|c|c|c|c|}
\hline \multicolumn{3}{|c|}{ Developing Asian countries } & $\begin{array}{c}\text { Developed Asian } \\
\text { countries }\end{array}$ \\
\hline Afghanistan & Indonesia & Philippines & Brunei \\
\hline Armenia & Kazakhstan & Sri Lanka & Hong Kong \\
\hline Azerbaijan & Kyrgyz Republic & Tajikistan & Japan \\
\hline Bangladesh & Malaysia & Thailand & Rep. of Korea \\
\hline Bhutan & Maldives & Turkmenistan & Singapore \\
\hline Cambodia & Mongolia & Uzbekistan & Taiwan \\
\hline China & Myanmar & Viet nam & \\
\hline
\end{tabular}




\begin{tabular}{|c|c|l|l|}
\hline Georgia & Nepal & & \\
\hline India & Pakistan & & \\
\hline
\end{tabular}

Source: J.Aleluia, P.Ferrao, "Assessing the costs of municipal solid waste treatment technologies in developing Asian countries"/ Waste management 69 (2017) 592-608.

Usually, local governments are responsible for MSW management, lack not only the financial resources, but also an effective management office [4, p.2]. In this case developing countries should analyse developed countries' experience to find out more effective way, and adopt their approach to own manner, and to save time and financial resources. For this reason authors wants to recommend an experience of Japan, one of the OECD countries, which is considered as forerunner in waste reduction and recycling [4, p.7].

In 1976 and 1977, OECD's Environment Committee conducted a review of Japan's environmental policies. They were very impressed with what had been achieved in Japan to reverse rising pollution trends. Within a very short period of time, the country moved from having one of the most polluted environments in the world, to having an environment that is generally comparable with other most OECD countries [5, p.13].

\section{Materials and methods}

The present research aims to find out more effective way of reducing $\mathrm{CO} 2$ on waste management sector and objective of the study became Yokohama city's MSW management. At the result of learning different literature about Japan Central government's "Eco-model cities" program, which was launched in 2008, Yokohama eco-model city's experience was notable in comparison with other cities. Located $30-40 \mathrm{~km}$ from Tokyo, the city is the second most populous city in Japan and was developed as an international port city [6, p.3]. Yokohama was designated as eco-model city in 2008 [7], and since that time became one of the forerunner in achieving targets on reducing waste amount.

Research has been done from February to April, 2020 and different methods have been used for this research as case study, data collection and analysis, especially from Yokohama city's official website, in which all (old and revised ones, new ones) action plans are presented to every resident or researcher.

\section{Results and discussion}

What policy makes the results of Yokohama city so distinguished? Yokohama city's population is growing every year, and waste quantity increases too with the population. Garbage treatment was changing too adopting to its population scale (Figure 1)

Figure 1. Transition of Garbage treatment 

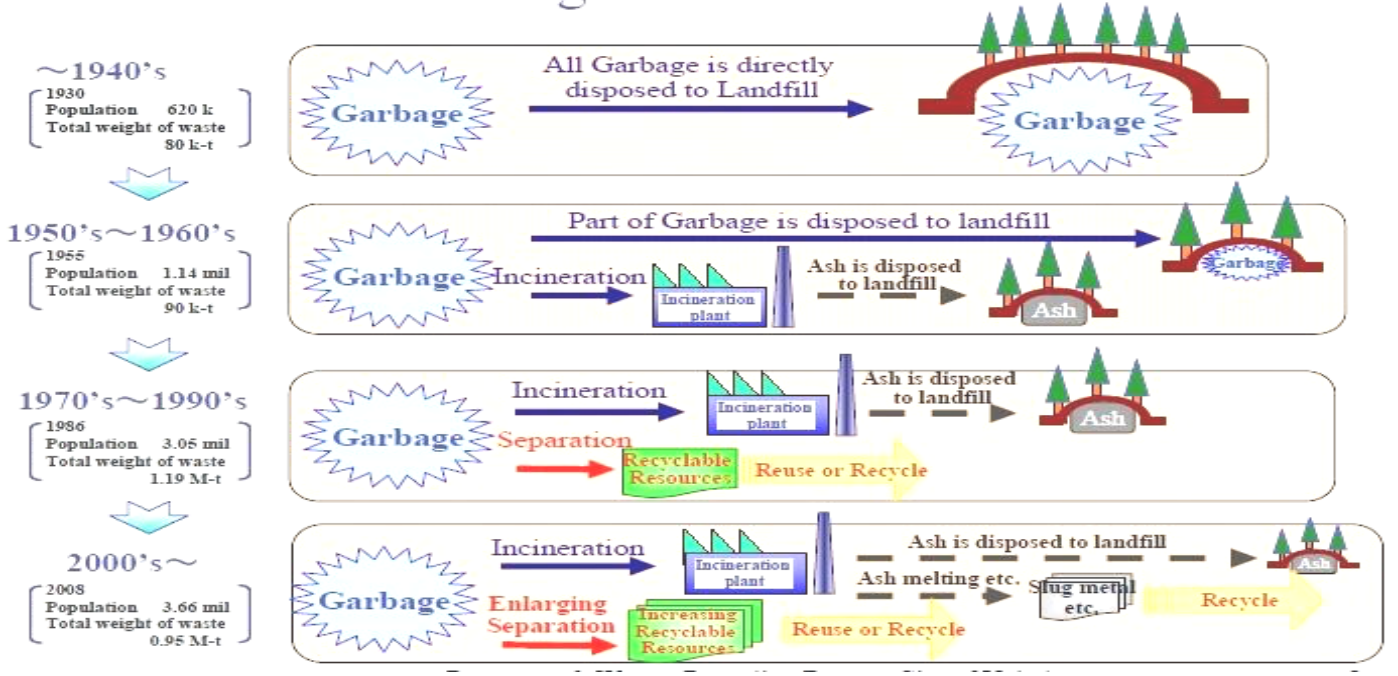

Source: Resources \& Wastes Recycling Bureau, City of Yokohama

The more population is, the more waste is generated, in the end more place is needed to final disposal. Unfortunately, Yokohama city and all other cities of Japan don't have enough places for landfills and final disposal (Figure 2).

Figure 2. Changes in the remaining capacity of the disposal site when the final disposal amount remains unchanged

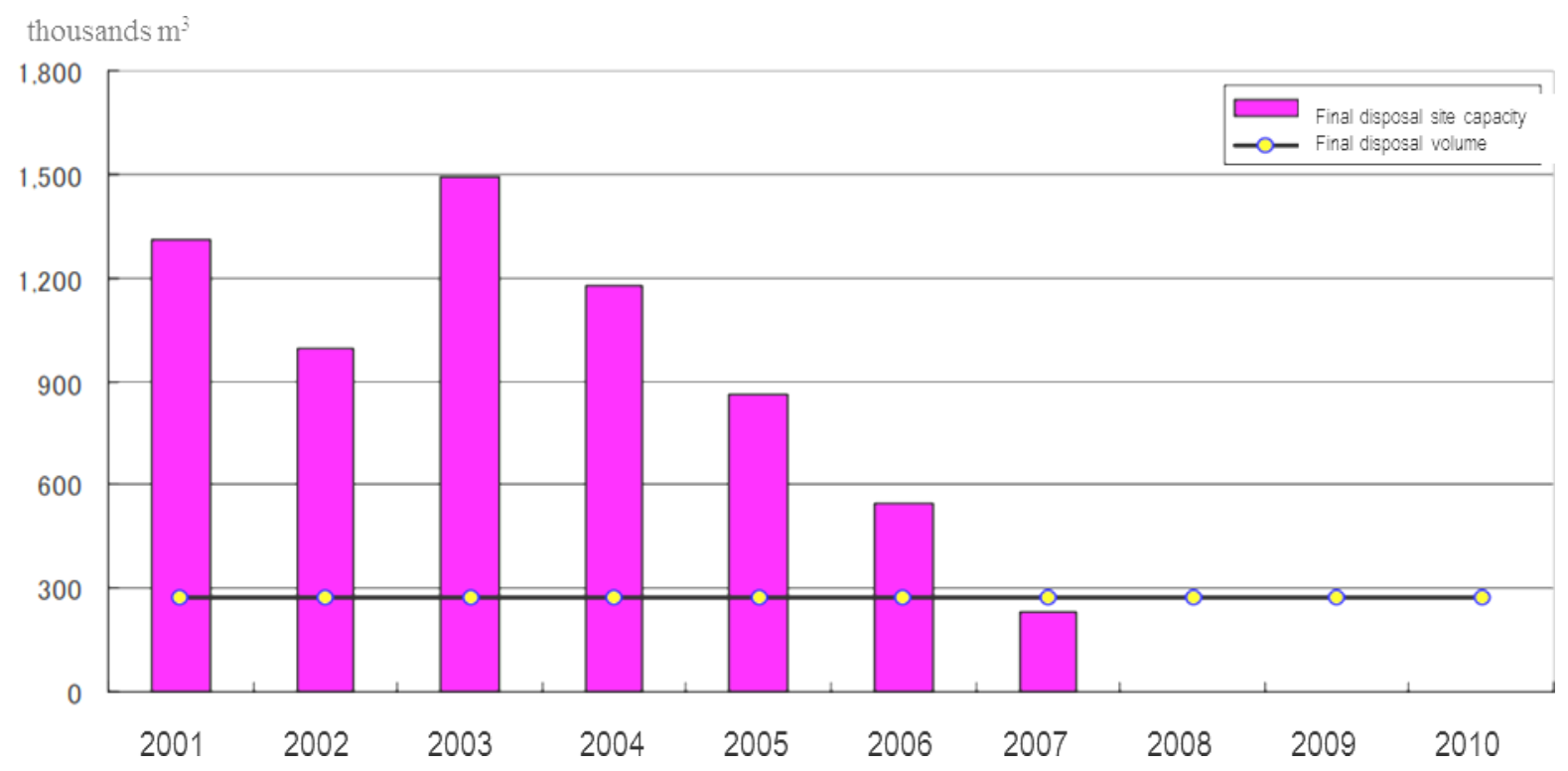

Source: Yokohama city’s official website. https://www.city.yokohama.lg.jp/

For this reason Yokohama city established the $30 \mathrm{G}$ Plan in 2003, "G" is for garbage and "30" represents the $30 \%$ goal the city has set for reducing waste use from 2001 to 2010 [1, p.39]. Actually Yokohama city not only achieved its goal, but exceeded expectations: reached target of cutting garbage volume by $30 \%$ ahead of schedule in two years through residents recycling efforts.

The following policy measures have produced such amazing results.

Initially five pillars were established for waste management based on the basic principles.

1. Citizens/companies and the government give support to each other, devise, devote themselves 
to each other, and work together to reduce the amount of waste and recycle it.

2. Based on an easy-to-understand goal, a system in which all citizens and businesses can participate and cooperate will proactively act toward the reduction and recycling of garbage.

3. Based on the concept of responsibility for polluters and responsibility for expanded producers, each of them will recognize and fulfil the roles of citizens, companies, and government.

4. Based on the priority of waste treatment such as "generation control/reuse/recycling, heat recovery, proper disposal", the 3Rs will be promoted, and still secure safely and stably the waste discharged as waste is.

5. Improvement activities that utilize the power of the people, including citizens and businesses, and measures to prevent illegal dumping, will be promoted to develop safe and clean towns.

Basic principles of Yokohama G30 plan: citizens, companies and the administration work together in promoting the 3Rs for waste, with the aim of realizing a "sound material-cycle society" where the consumption of resources and energy is reduced as well as reducing the environmental impact. Every group has its own role. For example, role of citizens is changing to an environmentally friendly lifestyle, rigorous sorting of garbage, etc. Role of the companies is design and production of products which reduce the emission of waste, collection and recycling of used products, etc. Role of the Administration is creation of systems for 3Rs, raising the awareness of people, provision and exchange of information, etc. At the end of 2008, more than 10,000 community meetings about waste and littering had been sponsored; 600 events were held to provide information about waste sorting rules and littering. And program managers had visited more than 3300 waste collection sites to assist citizens with waste sorting guidance. Separation briefings were organized about 11,000 times, educational campaign in front of train stations about 600 times (FY 2004-2005).

There is basic policy too for achieving goals:

1. "Citizens, businesses and governments share information" policy includes:

(1) Providing garbage and environmental information;

(2) Promotion of environmental education and learning;

(3) Promotion of dissemination and awareness activities.

2. "Citizens, businesses, and governments work together to promote waste reduction" policy includes:

(1) Enhancement of waste reduction and 3R promotion movement;

(2) Study of economic methods.

3. "Thorough waste separation and recycling" policy divides in two groups: Household waste measures and commercial waste measures. The first includes:

(1) Thorough separation and expansion of separate collection;

(2) Promotion of resource group recovery;

(3) Development of resource depot;

(4) Promotion of business recovery;

(5) Promotion of recycling of garbage. The second includes:

(1) Promotion of proper discharge and recycling by the polluter-companies;

(2) Promotion of proper delivery and recycling by a licensed companies;

(3) Initiatives by the city;

4. "Promotion of environmentally friendly waste treatment" policy includes:

(1) Collection and transportation;

(2) Maintenance and operation of recycling-related facilities;

(3) Operation and management of garbage incineration plant;

(4) Operation, management and maintenance of the final disposal site;

(5) Survey and research on recycling technology, processing technology, etc.

5. "Promotion of environmentally friendly and clean town development" policy includes:

(1) Promotion of beautification activities from the area;

(2) Promotion of measures to prevent illegal dumping [8].

Initially only 7 items have been sorted, later the number raised to 15 items as follows: 
Figure 3. Recyclables list of city of Yokohama
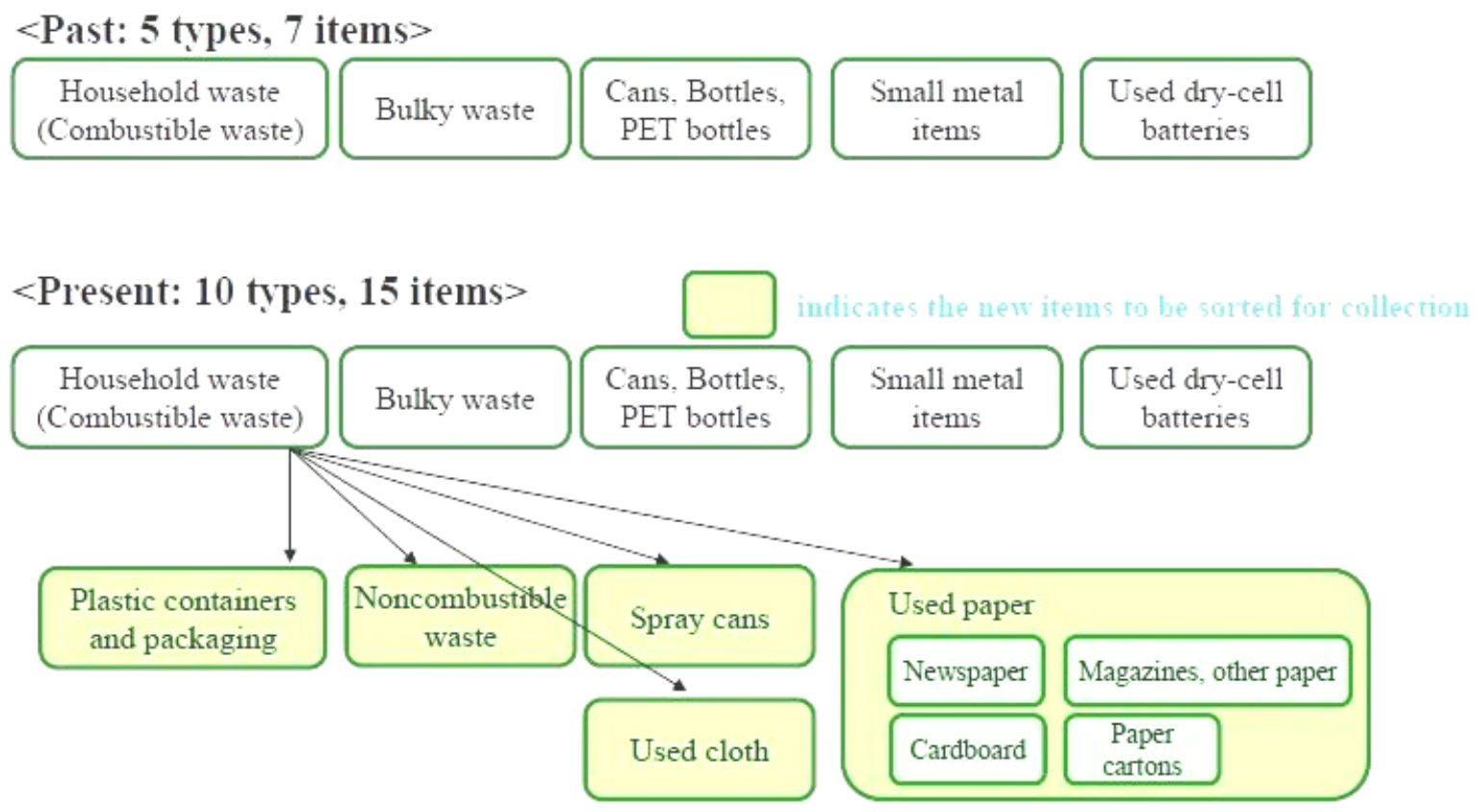

Source: 横浜市一般廃棄物処理基本計画, 2011 www.city.yokohama.lg.jp/

The city disposes burnable waste at the incineration plant, located in the city. Sakae Plant and Konan Plant were abolished in October 2005 and in November 2006 respectively due to the decrease in waste volume. The Hodogaya Plant was temporarily suspended in April 2010 and there were four plants (2011).

\section{Conclusion.}

The 30G Plan was established in 2003 by Yokohama city government to reduce waste use for 30\% from 2001 to 2010. In the result the city has achieved the goal in advance. For this reason the $30 \mathrm{G}$ plan became a research objective for this and other research works all over the world.

In the result of the research, the very first measures that followed to success were providing environmental information and promoting environmental education and learning. City administration in alliance with the companies and waste recycling, incineration plants, organized many guidance tours and delivery lectures to rise people's awareness. It was the first step in reducing waste amount. Other aforementioned policy measures were conducted too on achieving target. Concluding efforts of the G30 plan, the most considerable results are:

1) Two incineration plants (Sakae, Oct. 2005 - 1500 t/day and Konan, Nov. 2006 - 900 t/day) were closed down and one (Hodogaya, Apr. 2010 - 1200 t/day) was suspended due to a significant reduction in the amount of garbage.

2) $\mathrm{CO} 2$ emissions in FY 2009 were reduced by 900,000 tons when compared to FY 2001 (originally calculated by City of Yokohama with LCA method)

After the G30 Plan, city government established new «Yokohama 3R (slim) Dream» municipal solid waste management master plan for 2010-2025 in January, 2011. "3R Dream Plan" aims to reduce garbage and its impact on the environment by " $3 R$ ", and ensure the environment's richness to future generation. New plan is continuing old plan's basic principles; in addition, new one is going to reduce waste through garbage generation control, to deal with global warming and to reduce GHG emissions, to pursue safe, secure, and stable garbage processing. 
References::

1. Ivy Bee Luan Ong, Benjamin K. Sovacool, A comparative study of littering and waste in Singapore and Japan, 2012. Resources, Conservation and recycling 61: 35-42

2. Inglezakis V.J., Moustakas K., Khamitovac G., Tokmurzin D., Rakhmatulina R., Serik B., Abibak Y., Poulopoulos S.G., 2017, Municipal solid waste management in Kazakhstan: Astana and Almaty case studies, Chemical engineering Transactions, 56, 565-570. DOI:10.3303/CET1756095

3. Aleluia J., Ferrao P., Assessing the costs of municipal solid waste treatment technologies in developing Asian countries, 2017. Waste Management 69, 592-608.

4. Singh R.K., Yabar H., Nozaki N., Rakwal R. Analyzing waste problems in developing countries: lessons for Kathmandu, Nepal through analysis of the waste system in Tsukuba City, Japan. Journal of scientific research and reports, 2015: 1-13

5. MacNeill J., Environment policy in the 1980s, 大気污染学会誌(Taiki osen gakkaishi)、第15巻 (dai $15 \mathrm{kan}$ ), 1980: 13-20.

6. Hino K., Taniguchi A., Hanazato M., Takagi D., Modal shift from cars and promotion of walking by providing pedometers in Yokohama city, Japan, 2019. International Journal of Environmental research and public health. 16, 2144: 1-14.

7. http://future-city.jp/en/about/8.https://www.city.yokohama.lg.jp/cityinfo/yokohamashi/org/shigen/sonota/hoshin/g30/g30.files/0005_20180907.pdf 